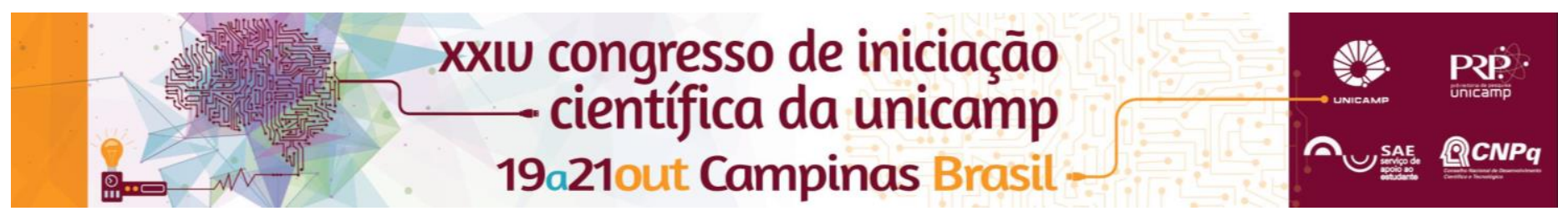

\title{
FOOD EXPERIENCES OF OVERSEAS STUDENTS FROM SCIENCE WITHOUT BORDERS PROGRAM.
}

\author{
Joyce Bolgar*, Sandra F. Gemma, Diogo T. Cunha, Caroline D. Capitani.
}

\begin{abstract}
The aim of this study was to analyze the experiences and eating habits of students from the University of Campinas Unicamp during the academic exchange of Science Without Borders program.
\end{abstract}

Key words: eating out; university students; exchange

\section{Introduction}

In the last years a high number of Brazilian university students have participated to academic exchange programs, such as the Science Without Borders (BETT, 2012). These adolescents and young adults have often extensive hours of studies and present lack of skills in the kitchen (ALVES, 2007), which collaborates to the higher consumption of processed food, also known as "ultraprocessed food", justified by the lack of required time for meal preparation. These factors can contribute to changing eating habits that lead to an increase in chronic diseases (PINHEIRO et al., 2004). Thus, the aim of this study was to analyze the experiences and eating habits of students from UNICAMP who participated to the Science Without Borders program (SWB).

\section{Results and Discussion}

All exchange students who participated to the SWB (2011-2015) were invited by e-mail to participate and to completed an online survey. The collected data were analyzed and the results reported according to the following categories:

- Characteristics of the SWB students: $80 \%$ of students $(n=215)$ who answered the survey has between 21 and 24 years. About gender, 48\% were female and $52 \%$ were male. Most of these students (58\%) were enrolled in Engineering, especially being $15.3 \%$ from Food Engineering (15.3\%), Chemical Engineering (12.5\%) and Mechanical Engineering (11.6\%). UNICAMP students went to 18 different countries especially the United Kingdom (22.8\%), Australia (18.6\%), United States (13.5\%) and Canada $(11.2 \%)$. The majority $(74 \%)$ remained in the country for two semesters.

When asked about weight gain or weight loss, $78 \%$ of participants reported change in weight during the exchange and $68 \%$ with weight gain.

- Feed characterization on campus: $47.2 \%$ of participants reported having University Restaurant (UR) on the university campus and among this, $71.56 \%$ reported attending the UR.
Chart 1. Characteristics of meals at the University restaurant $(n=73)$

\begin{tabular}{lllllc}
\hline Frequency of use of the UR & (n) & $(\%)$ & Meal quantity at the UR & (n) & $(\%)$ \\
\hline 1-2 times per week & 21.0 & 28.76 & One & 19.0 & 26.02 \\
3-4 times per week & 17.0 & 23.28 & Two & 12.0 & 16.43 \\
5-6 times per week & 11.0 & 15.07 & Three & 22.0 & 30.13 \\
Daily & 24.0 & 32.89 & Four or more & 20.0 & 27.41 \\
\hline Total & $\mathbf{7 3 . 0}$ & $\mathbf{1 0 0 . 0}$ & Total & $\mathbf{7 3 . 0}$ & $\mathbf{1 0 0 . 0}$
\end{tabular}

Chart 2. Characterization of the University restaurant meals $(n=73)$

\begin{tabular}{lccccccccccc}
\hline \multicolumn{1}{c}{ Similar meals } & \multicolumn{2}{c}{ Similar schedule } & \multicolumn{2}{c}{ Paid meals } & \multicolumn{2}{c}{ Subsidy } & \multicolumn{3}{c}{$\begin{array}{l}\text { Enjoyed the } \\
\text { meals }\end{array}$} \\
& $(\mathrm{n})$ & $(\%)$ & $(\mathrm{n})$ & $(\%)$ & $(\mathrm{n})$ & $(\%)$ & $(\mathrm{n})$ & $(\%)$ & $(\mathrm{n})$ & $(\%)$ \\
\hline Yes & 6.0 & 8.21 & 42.0 & 57.53 & 61.0 & 83.56 & 26.0 & 36.62 & 60.0 & 82.2 \\
No & 67.0 & 91.79 & 31.0 & 42.47 & 12.0 & 16.44 & 47.0 & 64.38 & 13.0 & 17.8 \\
\hline Total & $\mathbf{7 3 . 0}$ & $\mathbf{1 0 0 . 0}$ & $\mathbf{7 3 . 0}$ & $\mathbf{1 0 0 . 0}$ & $\mathbf{7 3 . 0}$ & $\mathbf{1 0 0 . 0}$ & $\mathbf{7 3 . 0}$ & $\mathbf{1 0 0 . 0}$ & $\mathbf{7 3 . 0}$ & $\mathbf{1 0 0 . 0}$ \\
\hline
\end{tabular}

Chart 3. Availability of other types of meal on the University campus $(n=215)$

\begin{tabular}{lllllllll}
\hline & $\begin{array}{l}\text { Cafes } \\
(\mathrm{n})\end{array}$ & $(\%)$ & \multicolumn{2}{c}{$\begin{array}{c}\text { Dining hall } \\
(\mathrm{n})\end{array}$} & \multicolumn{2}{c}{$\begin{array}{l}\text { Restaurants/fast-food } \\
(\mathrm{n})\end{array}$} & \multicolumn{2}{c}{$\begin{array}{l}\text { Residence near the university } \\
(\mathrm{n})\end{array}$} \\
\hline Yes & 208.0 & 96.74 & 164.0 & 76.28 & 108.0 & 50.23 & 159.0 & 73.95 \\
No & 7.0 & 3.26 & 51.0 & 23.72 & 107.0 & 49.77 & 56.0 & 26.05 \\
\hline Total & $\mathbf{2 1 5 . 0}$ & $\mathbf{1 0 0 . 0}$ & $\mathbf{2 1 5 . 0}$ & $\mathbf{1 0 0 . 0}$ & $\mathbf{2 1 5 . 0}$ & $\mathbf{1 0 0 . 0}$ & $\mathbf{2 1 5 . 0}$ & $\mathbf{1 0 0 . 0}$
\end{tabular}

\section{Conclusions}

There were differences between the eating habits of students when they were in another country observed for weight gain during the exchange. Although, $50 \%$ of the target universities do not present UR, but there are available cafes for students as well as dining hall equipped with microwave or other equipment for heating or for meal preparation. Future analysis will be applied on the collected data in order to observe the relationship between the results.

\section{Acknowledgement}

To CNPq/UNICAMP for the sponsorship concession.

Referências: ALVES, H. J.; BOOG, M. C. F. Rev. Saúde Pública, v. 41 n. 2, 2007.; BETT, D. Z. Monografia de Curso de Especialização. Porto Alegre: UFRGS, 2012.; PINHEIRO, A. R. O.; FREITAS, S. F. T; CORSO, A. C. T.. Rev. Nutrição, v. 17, n. 4, p. 523-533, 2004. 